\title{
Dwudziestowieczna Europa Środkowo-Wschodnia w rosyjskich i białoruskich atlasach historycznych początku XXI wieku (2005-2010)
}

\section{Grzegorz Strauchold}

W chwili, gdy rozpadł się Związek Sowiecki ${ }^{1}$, w najbliższym naszym sąsiedztwie powstało szereg państw sukcesyjnych. Przede wszystkim nadal potężna i potencjalnie groźna Federacja Rosyjska, granicząca z Polską poprzez obwód kaliningradzki usytuowany na miejscu części dawnych niemieckich Prus Wschodnich. Ogromne państwo o wielorakich problemach, proporcjonalnych do jego wielkości, a nade wszystko o bardzo słabych tradycjach demokratycznego bytu. Obecnie kraj kierowany $\mathrm{w}$ istocie autorytarnie, choć $\mathrm{z}$ zachowaniem nie tylko sztafażu demokratycznego, ale i pewnych form faktycznej demokracji. Litwa, związana w latach ostatnich z Polską poprzez przynależność do Unii Europejskiej i NATO - państwo w pełni demokratyczne ${ }^{2}$. Republika Białoruś, powiązana $\mathrm{z}$ Rosją formalnie układem tworzącym dwugłowy związek ponadpaństwowy (ZBiR - Związek Białorusi i Rosji), a ostatnio poprzez białorusko-rosyjsko-kazachską unię celną, faktycznie prowadząca politykę pełną meandrów. Jest to kraj mocno zrusyfikowany i zsowietyzowany, kierowany faktycznie po dyktatorsku. Choć i tutaj nie można nie zauważyć pewnych oznak demokracji3. Ukraina, państwo wstrząsane paroksyzmami politycznymi i wojnami gazowymi z Rosją. Aktualnie państwo na rozdrożu, łaknące - przynajmniej ustami swych elit i poglądami trudnej do sprecyzowania liczby mieszkańców - zbliżenia z demokratycznym Zachodem, a zarazem brutalnie szantażowane, stawiane przez Rosję w obliczu polityki militarnych faktów dokonanych: aneksja Krymu oraz podsycanie wystąpień zbrojnych rosyjskich separatystów, zamieszkujących w dużej liczbie Ukrainę zadnieprzańską. . W tej grupie naszych wschodnich sąsiadów Rosja i Białoruś wykazują w wydawnictwach z zakresu geografii historycz- nej zbieżne stanowiska (także z naszego polskiego punktu widzenia) w ocenie najważniejszych wydarzeń XX w. Niniejszy artykuł stanowi wstępną próbę ocenienia oficjalnej polityki historycznej rosyjskiej i białoruskiej, tamtejszej interpretacji wydarzeń, które nam, Polakom, wydają się najważniejsze. Jest to zatem spojrzenie na świat, a przede wszystkim na Europe Środkowo-Wschodnią z perspektywy Moskwy i Mińska. Ale też, jakby z drugiego rzędu, jest to moja prywatna recenzja rezultatu oglądania obcymi oczyma spraw najważniejszych dla Polski w XX w. Obejmuje ona przedział chronologiczny $1914-1989$.

Dodam, iż atlasy białoruskie wydawane są z osobna, choć nie komplementarnie dwutorowo - w wersji językowej rosyjskiej i białoruskiej. Nie zamierzam w stosunku do licznych atlasów rosyjskich - tj. opublikowanych w Rosji - wy-

1 W 1991 r. podjęto oficjalną decyzję o likwidacji Związku Socjalistycznych Republik Sowieckich.

2 Na temat stosunków polsko-litewskich w XX w. zobrazowanych przez polską i litewską kartografię historyczną i geopolityczną por.: G. Strauchold, D. Przybytek, Obraz stosunków polsko-litewskich w polskiej kartografii historycznej XX wieku, w: Polska i jej sąsiedzi. Studia z dziejów kultury, gospodarki i myśli politycznej. Księga pamiątkowa ofiarowana profesorowi Marianowi Mroczce w 70. rocznice urodzin, red. M. Hejger, W. Skóra, Pruszcz Gdański-Stupsk 2010, s. 677-684; G. Strauchold, D. Przybytek, Obraz stosunków polsko-litewskich w polskiej i litewskiej kartografii historycznej i geopolitycznej XX-XXI wieku, w: Wroctaw na litewskie millenium. Materiały z uroczystej konferencji z okazji 1000-lecia udokumentowania nazwy Litwa, red. A. Srebrakowski, G. Strauchold, Wrocław 2010, s. 47-65.

3 Na temat zagadnień terytorialnych w XX w. w Europie Środkowo-Wschodniej i ich zilustrowania w kartografii por.: G. Kosmala, Zmiany granic politycznych w Europie Środkowej w okresie ostatnich stu lat, Wrocław 1993; G. Strauchold, D. Przybytek, Skutki zmian terytorialnych w Europie Wschodniej po utracie przez Polskę niepodlegtości w 1939 r. oraz w momencie jej odzyskania w 1989 r., w: Polska i Białoruś w XX wieku. Z dziejów Europy Środkowo-Wschodniej, red. E. Czapiewski, G. Strauchold, Wrocław 2009, s. 165-177.

${ }^{4}$ Obraz przemian granicznych w ukraińskiej przestrzeni geopolitycznej został obficie zilustrowany w wielkim dziele ukraińnkiej kartografii lat ostatnich. Рor.: Національний атлас України, ред. Б.Е. Патон, Київ 2009. 
dawanych w kilku seriach dla różnych typów szkół przywoływać ich wszystkich w przypisach. Poniżej odwołam się do tych najważniejszych i najbardziej - moim zdaniem - reprezentacyjnych. By nie mnożyć rozbudowanych przypisów, w przypadku szkolnych atlasów historycznych, dla ich rozróżnienia, w odsyłaczach podaję także nazwy wydawnictw. Nie przytaczam natomiast - nieraz bardzo licznych - nazwisk redaktorów i autorów.

$$
* * *
$$

Przegrana dla Rosji wojna światowa lat 19141918 zakończyła się dla niej zapoczątkowaniem nieludzkiego eksperymentu społecznego realizowania utopijnej idei realnego socjalizmu (nazywanego przez dziesięciolecia komunizmem) - przedstawianego niezmiennie w historiografii sowieckiej jako początek okresu powszechnej szczęśliwości, który im dłużej trwa, tym bardziej świetlane perspektywy stwarza ludziom pozostającym w zasięgu marksistowskiej inżynierii dusz (z rewizjonistyczną domieszką leninizmu i stalinizmu). W rosyjskich wydawnictwach z zakresu geografii historycznej, publikowanych od rozpadu ZSRS w 1991 r., zagadnienia te - naturalnie - były ilustrowane i komentowane. Podobnie jak wydarzenia późniejszych dekad XX w.

Najnowszy dorobek Białorusi na polu geografii historycznej XX w. jest dość skromny. Ogranicza się do niewielkich wydawnictw przeznaczonych do szkó $1^{5} \mathrm{i}$ atlasu będącego w istocie zbiorczym wypisem z sześciotomowej Encyklopedii Biatorusi $i^{6}$. W 2009 r. ukazał się pierwszy

5 Por.: Атлас 8 класс. Всемирная история нового времени XIX - начало XX в., Минск 2008; Атлас 8 клас. Гісторыя Беларусі (XIX ст. - 1917 г.), Мінск 2007.

6 Por.: Атлас гісторыі Беларусі. Ад старажытнасці да нашых дзён, аўтар тэкста Л.У. Языковіч, Мінск 2006.

7 Por.: Вялікі атлас Беларусі у З-тамах, т. 1, ред. Г.І. Кузняцоў, Мінск 2009.

8 Por. z pomięciem w tym odsyłaczu licznych wydanych w Rosji szkolnych atlasów historycznych: История войн. Иллюстрированный атлас военной истории с древнейших времен до XXI века, [przekt. $\mathrm{z}$ angielskojęzycznej publikacji: The Times history of war, ed. I. Drari, Harper Collins Publisher 2000], Тверь-Москва 2008; История войн. Россия. Иллюстрированный атлас, сост. К.А. Залесский, О.В. Сухарева, А.А. Фетисов, Москва 2007; Россия. Полный энциклопедический иллюстрированный справочник в схемах, картах, таблицах, сост. Пётр Дейниченко, Москва 2008; Большой атлас России, ред. Ю.Н. Голубчиков, С.Ю. Шокарев, Москва 2005. Zdecydowałem się z trzech tomów wielkiego atlasu historii Białorusi ${ }^{7}$. Rosjanie w ostatnich latach wydali dużo więcej atlasów, korzystając również z opracowań anglosaskich ${ }^{8}$. Nadmienię, iż wydawnictwa publikowane w Rosji są powszechnie dostępne w księgarniach białoruskich.

W stosunku do ostatnich lat pierwszej wojny światowej w poglądach obu stron co do ważności poszczególnych wydarzeń rysuje się istotna różnica. Stopniowe wycofywanie się wojsk rosyjskich na wschód i próba przeciwstawienia się temu ofensywą Brusiłowa (1916) są faktami wspólnymi dla niemal wszystkich wydawnictw w obu państwach ${ }^{9}$. Nieco inaczej wygląda natomiast kwestia przejęcia władzy w Sankt Petersburgu i Rosji w wyniku puczu bolszewickiego w październiku (listopadzie) 1917 r. Z trzech analizowanych atlasów białoruskich tylko w jednym, przestawiając sytuację militarną w Europie w latach 1917-1918, umieszczono na terenie Rosji centra wystąpień rewolucyjnych, także na tle innych europejskich wydarzeń tego rodzaju ${ }^{10}$. W atlasach wydawanych w Rosji co zrozumiałe i naturalne - wybuch rewolucji jest mocno podkreślany i opisywany ${ }^{11}$. Najobszerniej rewolucja (1917) i porewolucyjna wojna domowa oraz walki na granicach są ilustrowane w najnowszym i największym Wielkim atlasie Rosji (tytuł oryg.: Большой атлас Poccuu $)^{12}$.

Dwa szkolne atlasy białoruskie (jeden w języku białoruskim, drugi w rosyjskim), przeznaczone dla 8 klasy szkoły podstawowej, mery-

traktować w tym wypadku wydawnictwo przettumaczone z języka angielskiego równorzędnie z opracowaniami rosyjskimi, wychodząc z założenia, iz wątki rosyjskie przed ich skierowaniem do druku podlegały uważnej weryfikacji ze strony redakcji rosyjskiego wydania tłumaczonego dzieła.

9 Por.: Новейшая история. XX - начало XXI века. 9 класс. Атлас, Москва 2007, s. 2-3; С.В. Колпаков, М.В. Пономарев, Атлас История России с древнейших времен до начала XXI века 10-11 классы, Москва 2007, s. 46; История России. Атлас, ред. Н.Н. Полункина, Москва 2005, s. 34; Атлас отечественная история XX век, Москва 2008, s. 6; История России. XX - начало XXI века. 9 класс. Атлас, Москва 2008, s. 6; Большой атлас, s. 337; История войн. Иллюстрированный, s. 169.

${ }^{10}$ Атлас 8 класс. Всемирная, s. 35.

11 Por. m.in.: Россия. Полный, s. 246-247; История войн. Россия, s. 145; История войн. Иллюстрированный, s. 169.

12 Большой атлас, s. 338-349.

\section{2 Studia Geohistorica $・ \mathrm{Nr}$ 02. 2014}


Dwudziestowieczna Europa Środkowo-Wschodnia w rosyjskich i białoruskich atlasach historycznych... Artykuty

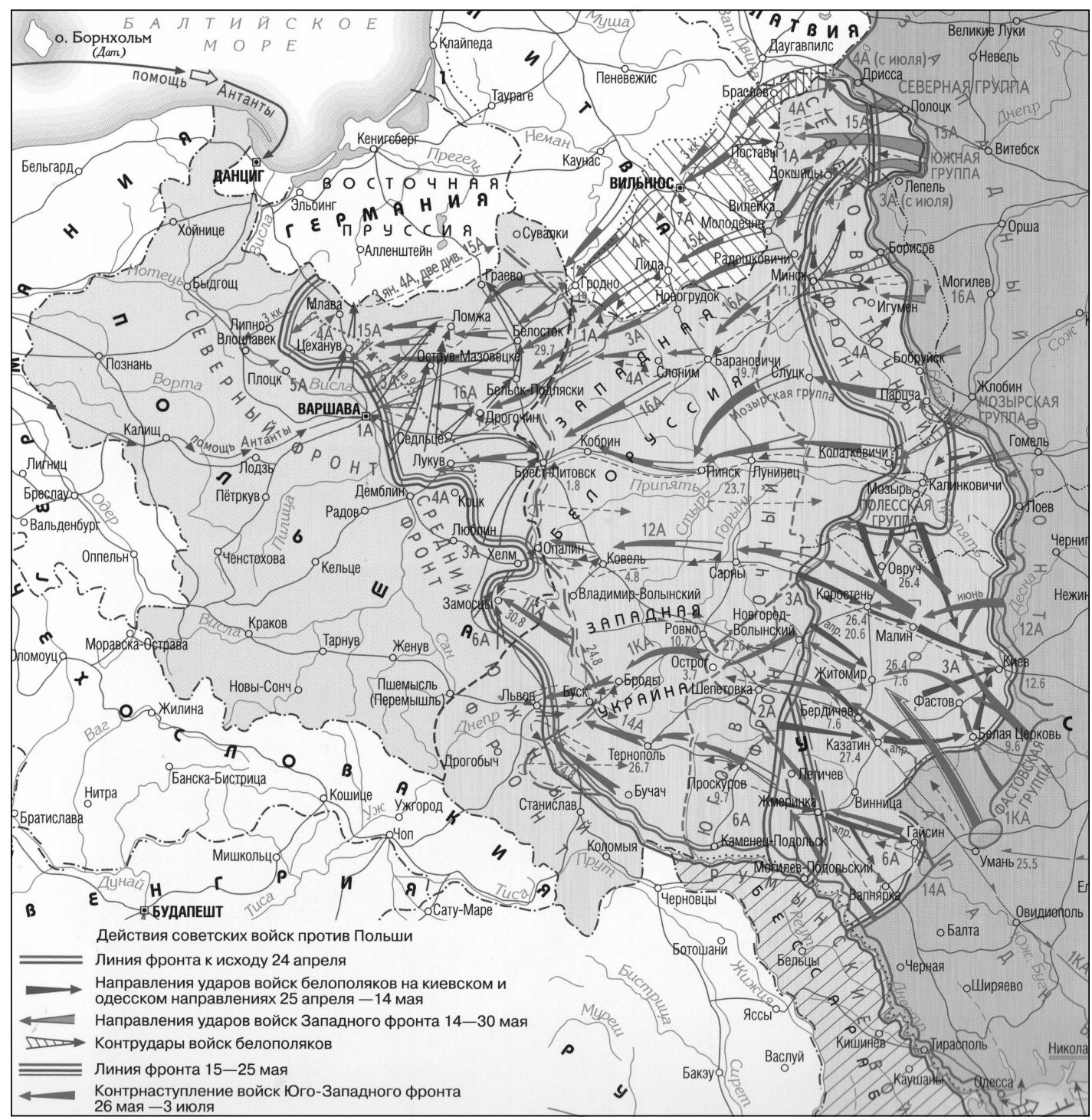

Mapa 1. Wojna polsko-sowiecka 1919-1921.

Źródło: «Большой атлас России», ред. Ю.Н. Голубчиков, С.Ю. Шокарев, Москва 2005, s. 348

torycznie nie wykraczają poza 1917-1918 r. Wydany w języku białoruskim atlas Ticmopas Беларусі (XIX cm. - 1917 2.) przedstawia wyłącznie sprawy białoruskie. Prezentowane zagadnienia osadzone są wyłącznie na obszarze uważanym za historycznie białoruski, niemniej na każdej mapie zaznaczone są w formie różowej wstążki współczesne granice Republiki Białoruś. Atlas wydany w języku rosyjskim na mapie Europy ilustrującej sytuację na frontach w latach 1917-1918 wskazuje również miejsca europejskich wystąpień rewolucyjnych - w tym w Pietrogradzie (Пеmpozpad), nazywanym po rosyjsku od początku Wielkiej Wojny w odróżnieniu od pierwotnej nazwy niemieckiej Sankt Petersburg (Санкт-Петербург) $)^{13}$.

13 Por.: Атлас 8 клас. Гісторыя; Атлас 8 класс. Всемирная, s. 35. 
Większy atlas, który stanowi część Encyklopedii biatoruskiej, sięga znacznie dalej w czasie od momentu końca Wielkiej Wojny, stanowiąc jedyne analizowane tu białoruskie opracowanie kartograficzne. Białoruski teatr wojny polsko-bolszewickiej ukazany jest w nim na tle zaznaczonym żółtą, wyraźną wstążką współczesnych granic Białej Rusi (tj. wyznaczonych formalnie w 1945 r.). Na mapie przedstawiającej lata 1918-1919 zaznaczone są skromnie, ale wyraźnie pod względem graficznym różne emanacje kształtującej się państwowości białoruskiej: niepodległościowa inicjatywa z marca 1918 r., powołanie sowieckiej republiki w styczniu 1919 r. oraz powołanie tzw. lit-biełu w Wilnie miesiąc później. Był to pomysł komunistów, ale nawiązujący w pewien sposób do tradycji Wielkiego Księstwa Litewskiego ${ }^{14}$. Mapa obrazująca lata 1919-1920 pokazuje białoruską republikę radziecką w granicach wynikających z pokoju ryskiego (1921), Wileńszczyznę w granicach Litwy, podobnie jak i Suwalszczyznę. Granica litewska nie dociera tu jednak do terenu niemieckich Prus Wschodnich, pozostawiając czytelnika w niepewności co do konkretnej przynależności tego niewielkiego terytorium. Im dalej jednak w głąb czasu i atlasu, tym sytuacja jest klarowniejsza. Po dokładnym rozrysowaniu „operacji warszawskiej” Armii Czerwonej latem 1920 r., kolejna mapa przedstawia terytorium tzw. Litwy Środkowej - wyodrębnionej, ale znajdującej się od 1922 r. w granicach Polski ${ }^{15}$. Jest to interpretacja faktu włączenia do Rzeczypospolitej Wileńszczyzny (zresztą na podstawie faktycznego plebiscytu, jakim były wybory do sejmiku wileńskiego), zupełnie odrębna od polskich poglądów wobec niezmiennego w tej sprawie - do dnia dzisiejszego - punktu widzenia historiografii i kartografii historycznej litewskiej $^{16}$, której bliskie są interpretacje rosyjskie,

\footnotetext{
14 Litewsko-Białoruska Republika Rad z siedzibą w Wilnie została powołana w lutym 1919 r. Faktycznie zlikwidowana w wyniku polskiej ofensywy w sierpniu 1919 r. Formalnie zlikwidowana przez samą siebie we wrześniu 1919 r. (jej władze w wyniku polskich postępów terytorialnych wycofały się do Smoleńska).

15 Атлас гісторыі Беларусі, s. 101, 103-104.

16 Por.: Lietuva žemélapinose. Lithuania on the Map, red. D. Gudiene, Vilnius 1999; Lietuvos istorijos atlasas, red. P. Gaučas, Vilnius 2001;
}

widzące Wileńszczyznę jako obszar zajęty przez Polskę kosztem Litwy ${ }^{17}$.

Atlasy rosyjskie (także thumaczony $\mathrm{z}$ angielskiego na rosyjski The Times history of war jako История войн. Иллюстрированный атлас военной истории с древнейших времен до XXI века) sążniście zilustrowały dzieje wojny domowej i operacje „sił antybolszewickich” wśród nich i polskich, niekiedy nazywanych merytorycznie poprawnie „polskimi wojskami” („польские войска") ${ }^{18}$. W reprezentacyjnych wydawnictwach rosyjskich znajdują się jednak także treści kuriozalne. W atlasie pt. Historia wojen. Rosja (История войн. Россия) w kampanii z 1920 r. Wojsko Polskie to „Białopolacy” („белополяки”). Nazwa ta wywodzi się z kilkudziesięcioletniej tradycji sowieckiej kartografii historycznej. To tak, jakby równoległe istnienie w strukturach Armii Czerwonej oddziałów polskojęzycznych (idąc całkiem subiektywnie tym wzorem, nazwałbym ich w takim razie „Czerwonopolakami”) stawiało je na równi z Polakami wyrąbującymi granice i ratującymi swoją niepodległość w obliczu zbrojnego marszu bolszewików na zachód Europy, „po trupie Polski” (M. Tuchaczewski). Podobnie przedstawia to zagadnienie Wielki atlas Rosji (Большой amrac Poccuu). W obydwóch opracowaniach jest zresztą ta sama mapa ${ }^{19}$. Zatem na ogół w rosyjskich wydawnictwach kartograficznych, opublikowanych już w XXI w., obowiązuje nadal komunistyczna nomenklatura, obecnie choć jednak nie zawsze - przyjmowana przez autorów najnowszych atlasów.

$$
* * *
$$

Interesujący, syntetyczny zestaw pięciu map Rosji (Rosji Sowieckiej i Związku Sowieckiego) - całej przestrzeni istnienia tego państwa - zawiera monumentalny Narodowy atlas Rosji (Национальный атлас России) z 2008 r. sygno-

Visuotinės istorijos atlasas mokykloms, red. R. Bugoreviciene, Vilnius 2004; G. Strauchold, D. Przybytek, Obraz stosunków polsko-litewskich w polskiej i litewskiej.

17 Por.: Россия. Полный, s. 264; Большой атлас, s. 348.

18 Россия. Полный, s. 264.

19 Por.: История войн. Россия, s. 151; Большой атлас России, s. 348. 
wany przez Ministerstwo Transportu Federacji Rosyjskiej i Federalną Agencję Geodezji i Kartografii ${ }^{20}$. Pierwsze dwie mapy obrazują sytuację terytorialną państwa w latach 1917-1922 i 1922-1929. Ich autorzy skonstatowali straty terytorialne w porównaniu do granic carskiej Rosji w wyniku powstania na jej zachodnich obrzeżach niepodległych państw oraz wewnętrzne przekształcenia - powstanie sowieckich republik i zmiany ich granic. Konsekwentnie wskazano Besarabię - do Wielkiej Wojny prowincję rosyjską - jako teren okupowany przez Rumunię. Dwie kolejne mapy, obrazujące przedziały czasowe 1929-1940 i 1940-1946, wskazały istotne zmiany granic bolszewickiej Rosji w wyniku prowadzonej w latach 1939-1945 ekspansji terytorialnej. Na nich to pokazano dotychczasowe ziemie państwa polskiego "połączone” („воссоединенныце) z białoruską i ukraińską republiką sowiecką na przełomie października i listopada 1939 r. Podstawą tych dat jest ,zjednoczeniowa” działalność powołanych przez władze sowieckie na okupowanych terenach polskich lokalnych przedstawicielstw ludowych. Oderwanie od Finlandii, napadniętej przez ZSRS w listopadzie 1939 r., Przesmyku Wyborskiego i Karelii uzasadniono na mapie traktatem pokojowym z marca 1940 r. owocującym ich „przyłączeniem” („присоединенныце). Odebranie w 1940 r. (w wyniku moskiewskiego ultimatum) od Rumunii Besarabii nazwano „zwróceniem” („возврашенныце) tych ziem ZSRS. Pozbawienie niepodległości republik bałtyckich (Litwy, Łotwy, Estonii) w 1940 r. nazwano w legendzie do odnośnej mapy „przyjęciem” („npuняmье") w skład ZSRS. Zastosowano zaiste zadziwiającą ekwilibrystykę językową wskazującą, że w tym akurat wydawnictwie stosowane od czasów stalinowskich uzasadnienia kolejnych agresji i zaborów terytorialnych nie wzbudziły chęci pogłębionej ich interpretacji $\mathrm{z}$ dystansu niemal siedemdziesięciu lat. $\mathrm{Na}$ marginesie dodam, iż sam ogromny przecież atlas w swej zasadniczej, stricte kartograficznej treści jest bardzo interesującym i wielkim osiagnięciem.

20 Por.: Национальный атлас России. Общая характеристика территории, ред. А.В. Бородко, Москва 2008, s. 38-41, 44.
Wydarzenia terytorialne - dalsze poszerzanie granic ZSRS w latach 1944-1945 podobnie sprawiają wrażenie rzeczowego przedstawienia. Jednak i tutaj odbiorca - choć trochę krytycznie nastawiony do współczesnej nam rosyjskiej interpretacji, w tym wypadku jej wyraźnie imperialnej części - może zauważyć zaskakujące informacje. Wspomniana już przeze mnie powyżej sprawa sowieckiej aneksji formalnie czechosłowackiej Rusi Zakarpackiej (bo przecież wcześniejsze włączenie jej w 1939 r. do Węgier było ewidentnym zaborem-okupacja) została skwitowana jako „włączenie” („включенная”). Podobnie jak okręg dotychczas fińskiego Petsamo (Pieczengi) „włączony" na podstawie dwustronnego traktatu pokojowego z $1947 \mathrm{r}$.

Całkowicie zależna od Moskwy Tannu-Tuwa na pograniczu mongolskim „weszła” (,Bomedmas") w skład ZSRS. Z kolei dotychczas japońskie Wyspy Kurylskie i południowy Sachalin zostały „przekazane” („nереданнысе) w wyniku konferencji jałtańskiej Wielkiej Koalicji w lutym 1945 r., na której jeszcze daleko przed kapitulacją Japonii strona anglosaska poczyniła wobec Moskwy wielkie obietnice w zamian za zobowiązanie się Stalina do złamania japońsko-sowieckiego traktatu o nieagresji i zaatakowanie tego państwa. Zatem bez kapitulacji i traktatu pokojowego sojusznicy „przekazali” sojusznikom określone tereny przeciwnika. Rzecz w historii wojen koalicyjnych niemal normalna i nierzadko stosowana. Także na mapie ilustrującej zmiany granic imperium $\mathrm{w}$ wyniku drugiej wojny światowej pokazano jedyne wówczas „straty” terytorialne Moskwy w 1945 r. - na rzecz Polski, której przekazano pewne ziemie. Owo „przekazanie” jest standardem wszystkich współczesnych atlasów rosyjskich (por. także poniżej). $\mathrm{Na}$ omawianej mapie, obrazującej sytuacje w 1945 r., znalazł się jednak błąd rzeczowy, w tym wypadku niezwiązany z interpretacją przesuwania sowieckich granic. Otóż zaznaczono także, jako dokonane w 1945 r., „przekazanie” Polsce niewielkiego terytorium w rejonie Bieszczad. Ta zmiana rzeczywiście miała miejsce, ale dopiero w roku 1951 i przeprowadzona była z inicjatywy ZSRS, której absolutnie 
wówczas zwasalizowana Polska nie mogła odrzucić. Wówczas też - a tego już na tej mapie nie zaznaczono - Polska oddała sowieckiej Ukrainie skrawek ziemi w rejonie miasteczka Bełz.

$* * *$

Początek kolejnego, drugiego światowego konfliktu w przypadku atlasu białoruskiego powią- zanego z sześciotomową encyklopedią przedstawiony jest z lokalnej, białoruskiej perspektywy. Można tam zobaczyć - co jest przejęciem interpretacji komunistycznej kartografii i wykładni historycznej - że prawną granicą Związku Sowieckiego podczas drugiej wojny światowej jest linia wyznaczona układem moskiewskim

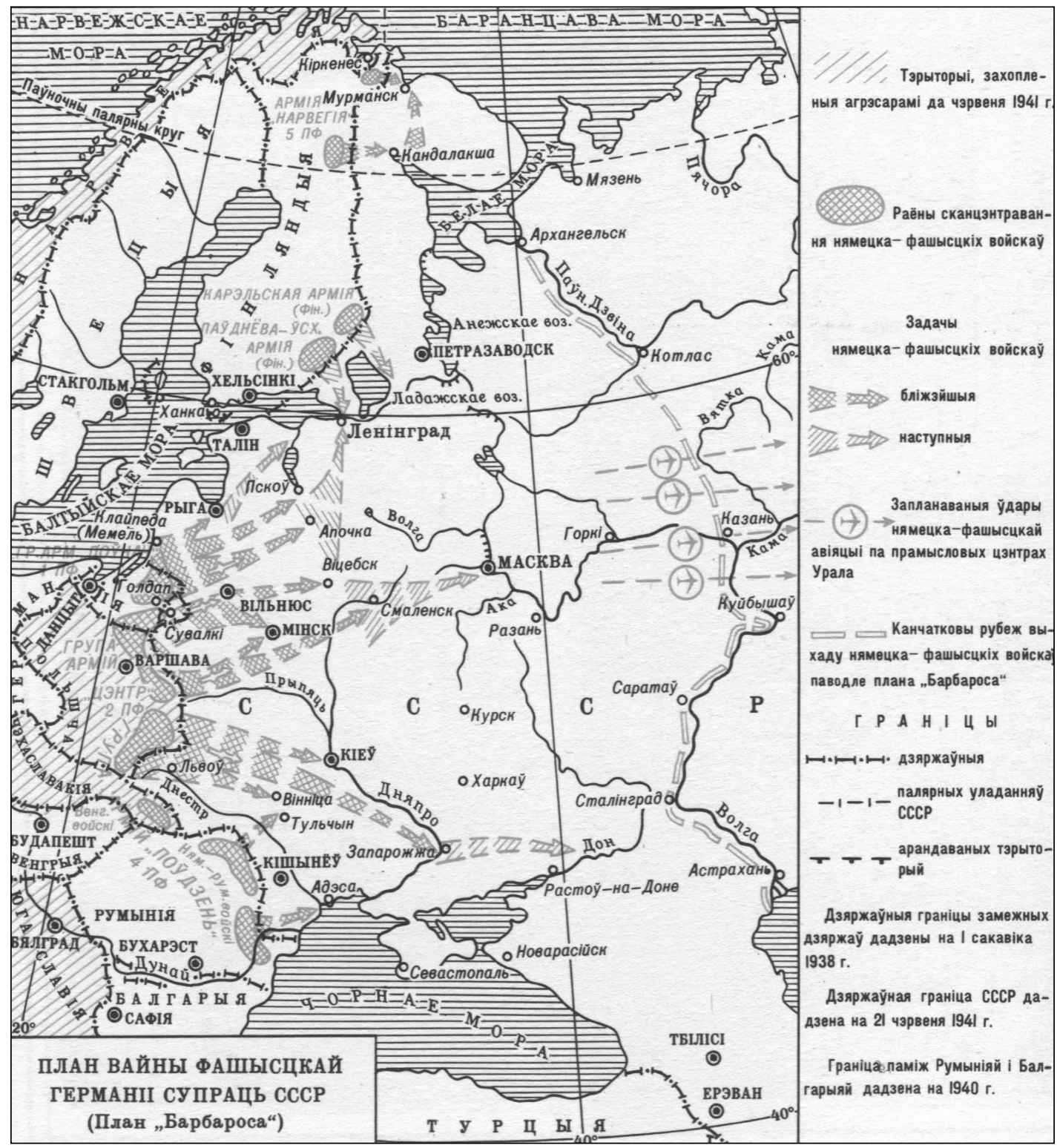

Mapa 2. Plan Barbarossa.

Źródło: «Атлас гісторыі Беларусі. Ад старажытнасці да нашых дзён», аутар тэксту Л.У. Языковіч, Мінск2006, s. 121 
z 28 września 1939 r. (tzw. drugi układ Ribbentrop-Mołotow $)^{21}$.

W myśl takiej interpretacji ówczesnego porządku geopolitycznego (formalnie wszak powiązanego $\mathrm{z}$ ustaleniami prawa międzynarodowego sprzed wybuchu drugiej wojny światowej) Polską było jedynie to, co w danym momencie okupowały Niemcy i enklawa Suwalszczyzny (także wcielona do Niemiec). Takie ukazywanie ówczesnych realiów granicznych było w czasach ZSRS i nadal jest cechą kartografii rodem z Rosji ${ }^{22}$. Wzmiankowany białoruski atlas historyczny kończy się wraz z końcem wojny światowej. Wszelkie kolejne, poniższe analizy będą się zatem tyczyć jedynie publikacji kartograficznych wydawanych w Rosji.

Moskwa niskim kosztem doprowadziła już w pierwszym miesiącu drugiej wojny światowej do odtworzenia swej zachodniej granicy z 1815 , a nawet z $1795 \mathrm{r}^{23}$ Wskazując takie daty, mam na myśli zachodnią granicę trzeciego zaboru rosyjskiego z 1795 r. wyznaczoną wzdłuż rzeki Bug, jak również wschodnią granicę Rosji utrwaloną postanowieniami Kongresu Wiedeńskiego w 1815 r. także na Bugu. Przyjęta od dawna powszechnie metoda - także w polskiej geografii historycznej - wskazująca granice Rosji po epopei napoleońskiej na zachód od linii Włocławek-Konin-Wieluń jakby ignoruje fakt istnienia odrębnego Królestwa Polskiego - powiązanego z Petersburgiem unią personalną, ale jednak osobnego państwa, którego władcą nie był car, lecz król z dynastii Romanowów.

Porozumienie radziecko-niemieckie o przyjaźni i granicy z 28 września 1939 r. - już po faktycznym zajęciu terytorium państwa polskiego przez niemiecki Wehrmacht i rosyjską (sowiecka) Armię Czerwoną - wyznaczyło, z niewielkimi zmianami, polsko-sowiecką granicę, która powstała następnie formalnie jako akt prawno-

21 Атлас гісторыі Беларусі, s. 121.

22 Por.: Большой атлас России, s. 365; История войн. Россия, s. 179.

23 Porównaj odnośne teksty porozumień sowiecko-niemieckich z 23 sierpnia i 28 września 1939 r. w: Stosunki Rzeczypospolitej Polskiej z państwem radzieckim 1918-1943. Wybór dokumentów, oprac. i wybór J. Komaniecki, Warszawa 1991; Zmowa. IV rozbiór Polski, oprac. A.L. Szcześniak, Warszawa 1990.

24 Por.: Большой атлас России, s. 365; История войн. Россия, s. 179. międzynarodowy 16 sierpnia 1945 r. Różnice dotyczyły terytorium północnego Podlasia z miastem Białystok, północno-wschodniego Mazowsza z miastem Łomża, a także niewielkich terenów pomiędzy rzekami San i Bug. Wymienione ziemie zostały w 1945 r. ,przekazane” $(\text { „переданные” })^{24}$ - zdaniem historiografii sowieckiej i rosyjskiej (po upadku ZSRS w 1991 r.) - odrodzonej po drugiej wojnie światowej Polsce kosztem terytorium Związku Sowieckiego. Przypomnę, iż do czasu wspomnianego sierpniowego porozumienia z 1945 r. pomiędzy rządem ZSRS a zależnym od niego, sterowanym przez

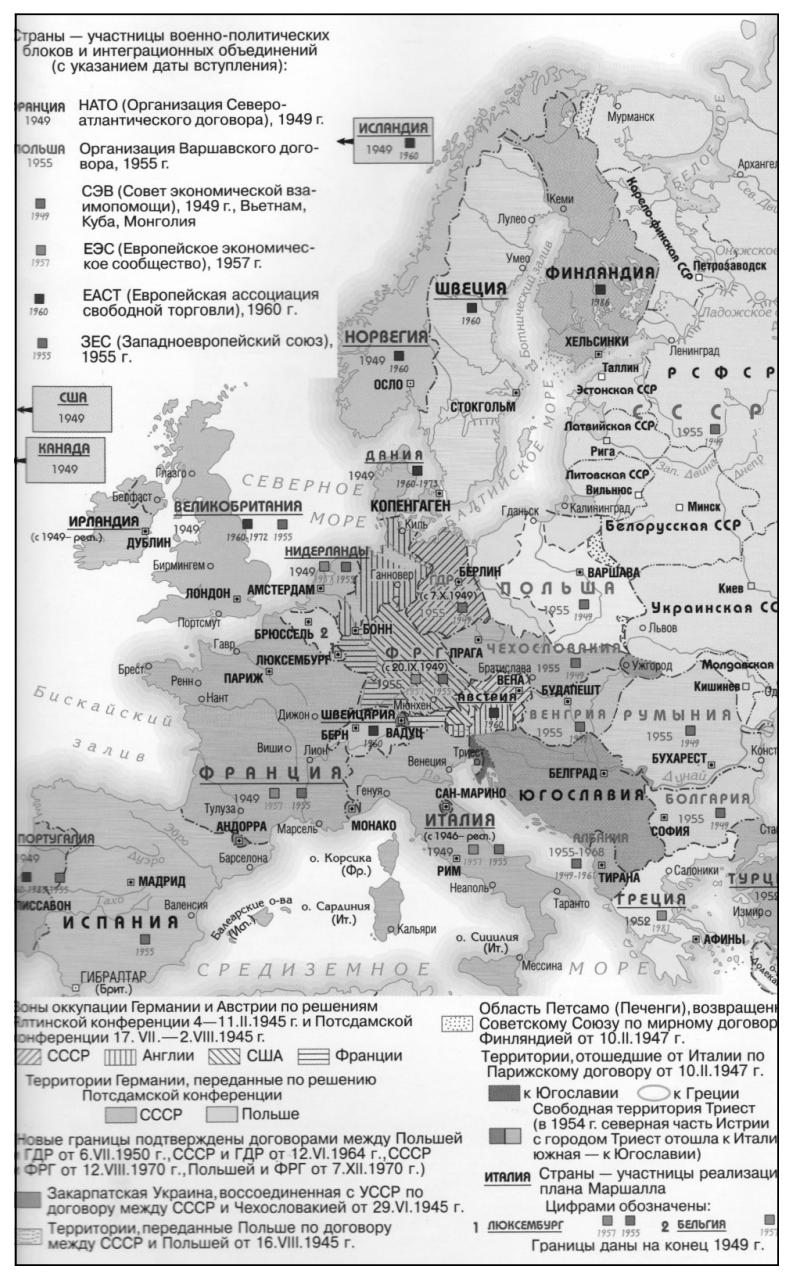

Mapa 3. Europa po drugiej wojnie światowej.

Źródło: «Большой атлас России», ред. Ю.Н. Голубчиков,

С.Ю. Шокарев, Москва 2005, s. 365 
komunistów, rządem polskim Rzeczpospolita w oczach prawa międzynarodowego istniała formalnie w granicach z $1938 \mathrm{r}$.

Widać też jednak wyraźne zmiany interpretacyjne, stanowiące wynik demokratyzacji Rosji i dopuszczenia w niej także innej wizji historii. W obszernym wydawnictwie o charakterze encyklopedycznym Россия. Полньий энциклопедический иллюстрированный справочник в схемах, картах, таблицах kampanii polskiej (także działań armii sowieckiej w Polsce) nie widać. Jest za to wojna zimowa z Finlandią 19391940 (tutaj w oryg. „советско-финляндскал война"), której granice Armia Czerwona „przekroczyła”, „przeszła” („,перешия”). Za to w wyodrębnionej tabeli najważniejszych wydarzeń 1939 r. wskazano dzień 1 września jako „początek drugiej wojny światowej” („начaлo Второй мировой войнъ»). Jest to przyjęcie interpretacji chronologii światowego konfliktu bezspornej dla spojrzenia zachodnioeuropejskiego (także polskiego) i atlantyckiego. O tyle istotne, iż w his-toriografii ZSRS, a później przez wiele lat $\mathrm{w}$ historiografii sukcesyjnej po tym państwie Federacji Rosyjskiej albo wyprowadzano genezę (jeśli nie początek) wojny światowej od agresji japońskiej w początkach lat 30. XX w. w Chinach, albo wskazywano początek tzw. wojny ojczyźnianej z Niemcami (od 1941 r.) jako wyraźnie bliższy rosyjskiemu widzeniu początku wojny światowej. W omawianym atlasie $\mathrm{w}$ tejże tabeli napisano, iż 16 (?) września 1939 r. Armia Czerwona „weszła”, „wkroczyła” („вcmynara”) do Polski. Choć w bezpośredniej narracji obok napisano, że to jednak 17 września wojska sowieckie "przeszły” („советские войска перешли”) granicę polską. Obecna w narracji informacja o układzie Ribbentrop-Mołotow z 23 sierpnia 1939 r. zawiera wzmiankę o rozgraniczeniu sfery wpływów Niemiec i ZSRS w Europie Wschodniej (zapewne z powodu różnicy czasu zamiast 23 sierpnia podany jest dzień następny). Co więcej, powołując się na tajny protokół do powyższego układu, napisano, że ZSRS zostanie odstąpiona część Polski ${ }^{25}$.

Proces przesuwania granic moskiewskiego imperium na zachód w latach 1939-1940 został zilustrowany wyraźnie, w sposób niepozostawiający czytelnikowi wątpliwości, kto był stroną napastniczą. W dwóch podstawowych atlasach rosyjskich przedstawione są te same mapy obrazujące działania wojsk niemieckich i sowieckich we wrześniu 1939 r. w Polsce, jak też aneksja republik bałtyckich $(1940)^{26}$. W tłumaczonym $\mathrm{z}$ angielskiego atlasie История войн o tych wydarzeniach (łącznie z Finlandia) wprost napisano (być może $\mathrm{w}$ bezpośrednim tłumaczeniu z oryginału) o „sowieckim natarciu, 1939-1940” („наступления”) ${ }^{27}$. Gwoli ścisłości warto dodać, iż w opracowaniu Больщой amлас Pоссии z 2005 r. narracyjna interpretacja polityki Józefa Stalina w latach 1939-1940 w Europie Środkowo-Wschodniej nie odbiega od widzenia tego momentu historii we współczesnej polskiej historiografii ${ }^{28}$.

Sygnalizując już wcześniej problem granic powstałych faktycznie w wyniku działań militarnych i politycznych 1939 r., więcej uwagi warto poświęcić politycznej przynależności okupowanych części Polski podczas drugiej wojny światowej, uwidacznianej we współczesnych atlasach rosyjskich. Tereny zajęte w wyniku kampanii 1939 r. przez Niemcy nazywane są konsekwentnie Polską. Uznawany jest zatem ówczesny status prawnomiędzynarodowy tego fragmentu Rzeczypospolitej. Tereny zajęte w wyniku najazdu rosyjskiego (sowieckiego), rozpoczętego - w porozumieniu z Niemcami z 23 sierpnia 1939 r. - 17 września 1939 r. przedstawiane są natomiast jako należące od tego czasu do ZSRS. Co więcej, na niektórych mapach pokazane są kierunki natarcia Armii Czerwonej w 1939 r., ale jednocześnie a priori wschodnie tereny polskie są na nich zaznaczone kolorami białoruskiej i ukraińskiej republiki sowieckiej. Jest to nie tylko nieuznawanie ówczesnego stanu prawnego, potwierdzanego przez układy polsko-radzieckie pomiędzy wojnami światowymi, ale również zagmatwanie ciągu przyczynowo-skutkowego. Nie jest jasne,

\footnotetext{
25 Россия. Полный, s. 280-282.

26 Por.: Большой атлас России, s. 355; История войн. Россия, s. 153.

27 История войн. Иллюстрированный, s. 199.

28 Большой атлас России, s. 355.
}

\section{IS 8 Studia Geohistorica $・$ Nr 02. 2014}




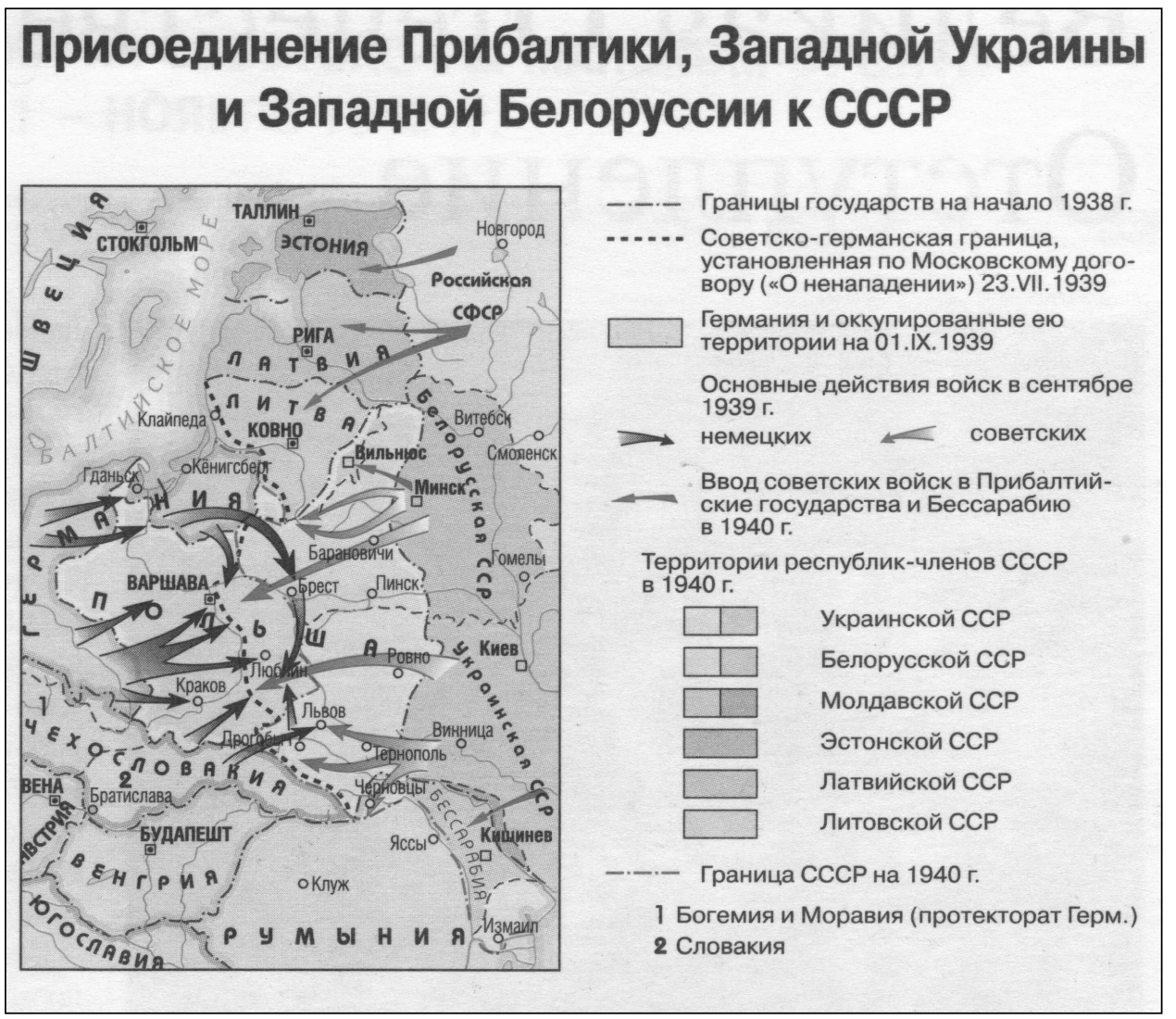

Mapa 4. Agresje niemieckie i sowieckie w Europie Środkowo-Wschodniej 1939-1940.

Źródto: "История войн. Россия. Иллюстрированный атлас», сост. К.А. Залесский, О.В. Сухарева,

Москва2007, s. 153

czy skutkiem najazdu Armii Czerwonej było wcielenie tych terenów do republik sowieckich, czy też najazd miał miejsce na zachodnich terenach tychże republik (sic! $)^{29}$.

Naturalnie uważna analiza legendy do map pokazuje stan faktyczny, niemniej takie zabiegi ich rysowników mają dobitnie pokazać ro-

29 Porównaj: Большой атлас России, s. 350, 355-356, 360; История войн. Россия, s. 153, 155, 167, 171; Россия. Полный, s. 284, 290. Ten sam punkt widzenia prezentują niektóre atlasy historyczne wydane po drugiej wojnie światowej poza Rosją i Polską. Por.: atlas wydany w komunistycznych Niemczech Wschodnich: Atlas zur Geschichte, hrsg. L. Berthold, Bd. 2, Gotha 1982, s. 46; atlas wydany w kapitalistycznych, demokratycznych, zjednoczonych Niemczech: Der Brockhaus Atlas zur Geschichte. Epochen, Territorien, Ereignisse, hrsg. J. Hotz, Mannheim-Leipzig 2007, s. 285.

30 Atlasy historyczne wydawane po drugiej wojnie światowej na demokratycznym Zachodzie opisywaną sytuację pokazywały w różny sposób. Poniżej kilka przykładów: syjskie racje przy wcieleniu do ZSRS terenów należących prawnie do Polski ${ }^{30}$. Dopełniając ocenę zachowawczości współczesnej rosyjskiej geografii historycznej, dodam, że wcielenie do ZSRS w 1945 r. Ukrainy Zakarpackiej zostało określona jako „połączenie” („воссоединение”) $\mathrm{z}$ sowiecką Ukrainą $\mathrm{w}$ wyniku porozumienia so-

1. Polska podczas wojny uległa podwójnej aneksji - w 1939 r. na rzecz Niemiec i ZSRR, w 1945 r. na rzecz ZSRR. Zarazem sama w tymże 1945 r. dokonała aneksji niemieckich terenów wschodnich. Por. R. McNally, Atlas of Word History, New York-Chicago-San Francisco 1957, s. 178-179, 186.

2. Polska w 1939 r. znalazła się pod podwójną okupacją. Istniała ona zatem formalnie w granicach przedwojennych, zaś dopiero w 1945 r. Rosja formalnie przesunęła swe granice na zachód. Por.: M. Nouschi, Maty atlas XX wieku. Historia [w ttum. z pol. uzup. na temat histori Polski w XX w.], Warszawa 2006, s. 90; Putzger historischer Weltatlas, hrsg. W. Leisering, Berlin 1990, s. 114; Putzger historischer Weltatlas, hrsg. E. Bruckmüller, C. Hartmann, Berlin 2006, s. 176-177. 
wiecko-czechosłowackiego z czerwca 1945 r. ${ }^{31}$ Uzupełnię, iż faktycznie Armia Czerwona teren ten (skądinąd w większości zamieszkany przez tzw. Karpatorusinów) zajęła/wyzwoliła, po czym Moskwa postawiła rząd czechosłowacki przed faktem dokonanej inkorporacji, wieńcząc zresztą w ten sposób proces zjednoczenia $\mathrm{w}$ jednym organizmie niemal całej historycznej Ukrainy, przynajmniej w jej zachodniej części, poza wskazywaną przez współczesną historiografię ukraińską Chełmszczyzną, znajdującą się w granicach Polski.

Rozpad Wielkiej Koalicji po drugiej wojnie światowej, podział Niemiec i zimna wojna we wszystkich większych rosyjskich wydawnictwach kartograficznych zostały dokładnie rozrysowane. Ciekawiej jawią się interpretacje tych faktów. W spokojnych narracjach opisano niemożność zachowania wojennej, alianckiej współpracy z powodu zbyt dużych różnic światopoglądowych dwóch systemów. Zdaniem autorów komentarzy do map, te konkurujące ze sobą systemy polityczno-ustrojowe były od siebie tak różne, że nie mogły ze sobą blisko, symbiotycznie koegzystować32.

Przedostatnia mapa Wielkiego atlasu Rosji przedstawia Wspólnotę Niepodległych Państw, oszczędnie opisując fakt ogłaszania niepodległości przez kolejne republiki. Brak jakiejkolwiek informacji o dezintegracji obozu państw wasalnych w Europie i upadku agresywnego Układu Warszawskiego. Na ostatniej mapie przedstawiona jest Federacja Rosyjska na przełomie tysiącleci $^{33}$. Brak odniesienia do ostatniego okresu

3. Polska została w 1939 r. podzielona pomiędzy Niemcy i ZSRR, zatem zachodnia granica Rosji została wyznaczona przez porozumienie rosyjsko-niemieckie z 28 września 1939 r. Na mapie Rzeczypospolitej w granicach poczdamskich z 1945 r. zaznaczono okręg białostocki jako oderwany od Polski w 1939 r. na rzecz ZSRR i na powrót oddany Warszawie w 1945 r. Por.: A.F. Chew, An Atlas of Russian History. Eleven Centuries of Changing Borders, London 1970, mapa 31-32. Podobnie pokazany rozbiór Polski w 1939 r. w: The Times History of Europe. 3000 Years of History in Maps, London 2003, s. 178; P.R. Magocsi, Historical Atlas of Central Europe, Seattle 2002, s. $178,186$.

4. Uznanie rozbioru Polski za rzeczywistą zmianę granic. W konsekwencji mapa dotycząca drugiej wojny światowej mianem Polska („Poland”) - czego nie robiła nawet kartografia nazistowska nazwała tereny tzw. Generalnego Gubernatorstwa kontrolowanego w historii jest nawet zrozumiały. Wygląda to tak, jakby nie był to jeszcze czas, który można by określać i szerzej interpretować historycznie. To wciąż jeszcze zajęcie bardziej dla politologów. Autorzy tego wielkiego wydawnictwa ograniczyli się do zaledwie zarysowania problematyki rosyjskiej, nie podejmując w żaden sposób kwestii - nieraz nadal zaognionych - na swych dawnych terytoriach, teraz znajdujących się w tzw. niedalekiej zagranicy.

$\mathrm{Za}$ bodaj najnowsze podsumowanie stosun$\mathrm{ku}$ rosyjskiej geografii historycznej do dynamicznych wydarzeń XX w. można uznać opublikowany w 2010 r. Petny historyczny atlas Rosji (Полный исторический атлас России) ${ }^{34}$. W swoich - ilustrowanych odnośnymi mapami - interpretacjach nie odbiega on typowych dla sowieckiej, a potem rosyjskiej historiografii (i propagandy) ocen wydarzeń rozgrywających się $\mathrm{W}$ związku $\mathrm{z}$ istnieniem bolszewickiego państwa. Co ciekawe, w legendzie mapy obrazującej wojnę domową w Rosji wskazano z nazwiska „białych” dowódców prowadzących działania przeciw bolszewikom. Pokazane na mapie działania wojsk polskich zostały zaś opisane jako „działania” na froncie zachodnim (s. 149). Na kolejnej mapie (s. 150) wojna polsko-bolszewicka została jednak szczegółowo zobrazowana. Strona polska to - tradycyjnie już - „białopolacy”. Wileńszczyzna zaś to teren „zdobyty” lub „zgarnięty” („захваченние) przez Polskę. Można zrozumieć taką interpretację. Wycofujący się pod naporem Wojska Polskiego bolszewicy przekazali Wilno Litwinom,

przez Berlin. Pozostałe tereny państwa polskiego ukazane zostały jako integralnie należące do Niemiec i ZSRR. Na mapie pokazującej sytuację z 1 stycznia 1945 r. mianem Polska określono tę część Generalnego Gubernatorstwa, która nadal była pod okupacją niemiecka. Nie zaznaczono natomiast ani formalnie istniejących granic Polski z 1938 r., ani granic tzw. Polski lubelskiej (z tymczasową stolica w Lublinie), która była niewielkim rosyjskim satelitą utworzonym przez Moskwę na terenie pomiędzy Bugiem (linia Curzona) i Wisłą. Por.: C. McEvedy, The Penguin Atlas of Recent History: Europe Since 1815, b.m. 1987, s. 75-87.

31 Большой атлас России, s. 365.

32 Por.: tamże, s. 364-365; История войн. Россия, s. 178-179.

33 Большой атлас России, s. 368-371.

34 Por. Полный исторический атлас России, зав. ред. О.В. Сухарева, отв. ред. К.А. Залесский, Москва 2010. 
a Polacy zdezawuowali ten gest akcją wojska gen. Lucjana Żeligowskiego. Na tejże mapie Besarabia - zgodnie z oficjalną interpretacją sowieckiej Rosji - wskazana została jako teren okupowany przez Rumunię. Na kolejnej, wielkoskalowej mapie ilustrującej „wykształcenie się”, „ukształtowanie się” („образование”) ZSRS (s. 154-155) wskazano zajęte w latach 30. i 40. XX w. terytoria bez przedstawienia jakichkolwiek okoliczności ich włączenia do ZSRS.

Jedyną informacją jest podanie rocznych dat. Nie ma nic o agresji na Polskę w 1939 r. oraz o zajęciu ponad $50 \%$ jej terytorium. Jest za to ukształtowana $\mathrm{w}$ ten sposób granica ZSRS z „Polską", która to wówczas w tej wska- zanej części była okupowana przez Niemcy. Tego faktu na odnośnej mapie nie zaznaczono. W odniesieniu do pozyskania terenów rumuńskich i fińskich, wskazano - dla tej pierwszej - „przekazanie” Besarabii, a dla drugiej „utracenie” (tereny „отомедшие”) Przesmyku Wyborskiego i Karelii.

Podsumowanie ukształtowania granic Europy w wyniku drugiej wojny światowej stanowi niewielka mapka ze s. 177 . Na niej to tereny wschodnie utracone przez Niemcy na rzecz Polski i Związku Sowieckiego zostały określone jako „przekazane” w wyniku poczdamskiej konferencji zwycięskich mocarstw. Ruś Zakarpacka została włączona do sowieckiej Ukrainy

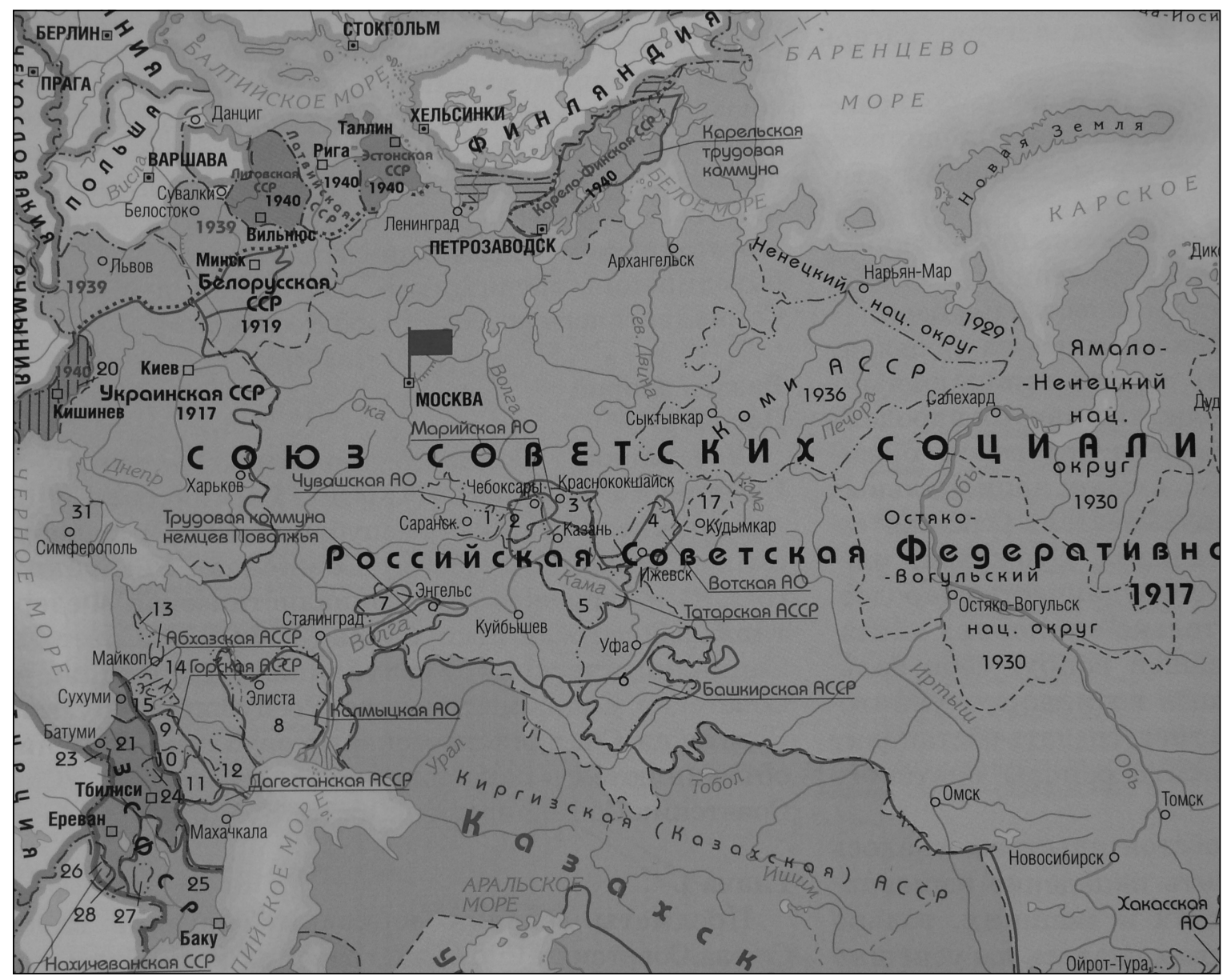

Mapa 5. Ekspansja terytorialna ZSRS w Europie 1939-1940.

Źródło: «Полный исторический атлас России», ред. О.В.Сухарева, К.А.Залесский, Москва, 2010, s. 154 
na podstawie odnośnego porozumienia sowiecko-czechosłowackiego. Podobnie w stylu już opisywanym przeze mnie powyżej zinterpretowano oderwanie od Finlandii Petsamo (Pieczengi) i „przekazanie” Polsce Białostocczyzny oraz kawałka Kurpiów z Łomżą. Także w tym atlasie wymiana terytoriów pomiędzy Polską a ZSRS w 1951 r. zilustrowana została jako dokonana w 1945 r. Także tutaj nie zauważono, że Warszawa w wyniku tego porozumienia oddała pewne tereny sowieckiej Ukrainie. Bardziej interesująca jest jednak mapa znajdująca się obok (s. 176-177). Przedstawia ona zimną wojnę w przestrzeni atlantyckiej - od Uralu po zachodnie krańce Stanów Zjednoczonych. Pokazano na niej rozmieszczenie wojsk lotniczych i rakietowych oraz wskazano zasięg rakiet stron konfliktu na terytorium przeciwnika. Poniżej mapy umieszczono obszerny cytat z przemówienia Winstona Churchilla w amerykańskim Fultonie w marcu 1946 r. Jest ono zgodnie przyjmowane przez historyków jako skonstatowanie istnienia przepaści pomiędzy komunistycznym, stalinowskim Wschodem a demokratycznym, opartym o USA Zachodem. W tym kompleksie map dość niepełna wydaje się ta ilustrująca rozmieszczenie wojsk i sztabów stron przeciwnych na terenie podzielonych Niemiec. Jest ona w ogóle pozbawiona legendy i nie zaznacza np. stacjonowania na terenie Polski Północnej Grupy Wojsk Sowieckich.

Interesującą, syntetyzującą ilustracją jest mapa przedstawiająca schyłkowy okres istnienia ZSRS. Pokazano na niej katastrofę atomową w Czarnobylu, a także wystąpienia niepodległościowe przeciw dominacji Moskwy w poszczególnych republikach związkowych na przełomie lat 80. i 90. XX w.

Analiza rosyjskich atlasów historycznych pozwala na stwierdzenie, iż tamtejsza historiografia nadal ma problemy z ustosunkowaniem się do wydarzeń rewolucji i wojny domowej podczas pierwszej wojny światowej i bezpośrednio po niej. Można odnieść wrażenie, jakby tamtejsi badacze i autorzy nie bardzo wiedzieli, jak potraktować to zjawisko: czy jako wielkie - jakkolwiek by patrzeć - zjawis- ko historyczne czy jako początek „imperium zła”. A może wydarzenia te postrzegać jako początek wspaniałego dla ludzkości eksperymentu społecznego? Wyraźnie łatwiej autorzy atlasów poradzili sobie z zagadnieniami polityki ZSRS i jej konsekwencji dla sąsiadów w latach 1939-1940. Ilustracje (mapy), bez względu na różnice semantyczne w legendach, wyraźnie wskazują, kto był agresorem. Także komentarze do map, powołując się bezpiecznie na poglądy Józefa Stalina (wskazywanego w takich wypadkach expressis verbis) są zrozumiałe i nie budzą sprzeciwów. Słabością rosyjskich atlasów (i nie tylko rosyjskich) są czasy najnowsze. W atlasach specjalistycznych, dotyczących wojen, znajdują się odnośne opisy, np. konfliktu w Czeczenii ${ }^{35}$. Jednakże z fundamentalnego wydawnictwa ostatnich lat, Wielkiego atlasu Rosji, niewiele można się dowiedzieć o kulisach bankructwa komunizmu i upadku czerwonego imperium.

O ile dobrze eksplorowałem rynek księgarski białoruski, to mogę stwierdzić, iż tamtejsza geografia historyczna w latach ostatnich nie miała dotychczas okazji, by szerzej zilustrować sytuację w Europie Środkowo-Wschodniej w XX w. ze współczesnego punktu widzenia. Wydanie w 2009 r. pierwszego tomu Wielkiego historycznego atlasu Biatorusi (sięgającego na razie tylko do końca średniowiecza) daje duże nadzieje na przyszłośśc ${ }^{36}$

W odniesieniu do rosyjskich i białoruskich atlasów historycznych należy podkreślić, iż na ich treść kartograficzną i prezentowane interpretacje historyczne niewątpliwie ma wpływ kilka czynników. Wśród nich bezsprzecznie wytyczne programowe nauczania (w przypadku atlasów szkolnych), wynikające z kolei z charakteru ustrojowego tych państw. Zarazem nie można nie dostrzegać w zaprezentowanych osądach historycznych Rosjan i Białorusinów efektów dokonanych, ale i nadal dokonywanych na przestrzeni ostatnich kilku dekad przewartościowań historycznych. Atlasy naszych słowiańskich

\footnotetext{
35 История войн. Россия, s. 182-183.

$36 \mathrm{~W}$ momencie oddawania tekstu do druku ukazał się drugi tom tego wydawnictwa.
} 
wschodnich sąsiadów nie są kopią wydawnictw z czasów ZSRS. Naturalnie nie są też dziełami o treściach pasujących ,jak ulał” do oczekiwań historycznych Polaków. Dla polskiego odbiorcy

\section{Literatura}

Аржакова М.М., Якубский В.А., К вопросу об освещении событий сентльря 1939 в учебной и научно-популярной литературе, „Studia Slavica et Balcanica Petropolitana [St. Petersburg]", 1-2 (5/6), 2009, s. 37-44.

Eberhardt P., Polska i jej granice. $Z$ historii geografii politycznej, Lublin 2004.

Kampf der Karten. Propaganda- und Geschichtskarten als politische Instrumente und Identitätstexte, hrsg. P. Haslinger, V. Oswalt, Marburg 2012.

Kamusella T., School History Atlases as an Instrument of Nation-State Making and Maintenance: A Remark on the Invisibility of Ideology in Popular Education, ,Journal of Educational Media, Memory, and Society”, 2 (1), 2000, s. 113-138.

Konopska B., Polskie atlasy historyczne. Koncepcje i realizacje, Warszawa 1994.

Kosmala G., Zmiany granic politycznych w Europie Srodkowej $w$ okresie ostatnich stu lat, Wrocław 1993.

Stosunki Rzeczypospolitej Polskiej z państwem radzieckim 1918-1943. Wybór dokumentów, oprac. i wybór J. Komaniecki, Warszawa 1991.

Strauchold G., Polskie mapy historyczne po 1945 roku jako forma indoktrynacji politycznej, „Forum Naukowe Wyższej Szkoły Zarządzania i Bankowości w Poznaniu”, 11 (5), 2006, s. 171-184.

Strauchold G., Szkolna mapa historyczna dokumentem czasu. Dzieje Polski i świata ostatniego pótwiecza, w: Mapa w pracy historyka, red. T. Bogacz, B. Konopska, Wrocław-Warszawa 1999, s. 145-153 (Z Dziejów Kartografii, 11).

\footnotetext{
37 Na temat roli kartografii historycznej jako narzędzia dydaktyki, ale i zarazem doraźnej propagandy państwowej por. m.in.: T. Kamusella, School History Atlases as an Instrument of Nation-State Making and Maintenance: A Remark on the Invisibility of Ideology in Popular Education, „Journal of Educational Media, Memory, and Society”, 2 (1), 2000, s. 113-138; G. Strauchold, Polskie mapy historyczne po 1945 roku jako forma indoktrynacji politycznej, „Forum Naukowe
}

tych dzieł jest to zapewne irytujące, ale taka jest natura dyskursu politycznego i historycznego państw o przeciwstawnych celach ustrojowych i geopolitycznych ${ }^{37}$.

Strauchold G., $Z$ zagadnień granicy polsko-radzieckiej uksztattowanej w wyniku II wojny światowej, „Studia Slavica et Balcanica Petropolitana [St. Petersburg]", 1-2 (5-6), 2009, s. $25-36$.

Strauchold G., Przybytek D., Obraz stosunków polsko-litewskich $w$ polskiej i litewskiej kartografii historycznej i geopolitycznej XX-XXI wieku, w: Wroctaw na litewskie millenium. Materiaty $z$ uroczystej konferencji $z$ okazji 1000-lecia udokumentowania nazwy Litwa, red. A. Srebrakowski, G. Strauchold, Wrocław 2010, s. 47-65.

Strauchold G., Przybytek D., Obraz stosunków polsko-litewskich w polskiej kartografi historycznej XX wieku, w: Polska i jej sasiedzi. Studia z dziejów kultury, gospodarki i myśli politycznej. Ksiegga pamiątkowa ofiarowana profesorowi Marianowi Mroczce $w$ 70. rocznice urodzin, red. M. Hejger, W. Skóra, Pruszcz Gdański-Słupsk 2010, s. 677-684.

Strauchold G., Przybytek D., Skutki zmian terytorialnych $w$ Europie Wschodniej po utracie przez Polske niepodlegtości w 1939 r. oraz w momencie jej odzyskania w 1989 r., w: Polska i Biatoruś w XX wieku. Z dziejów Europy Środkowo-Wschodniej, red. E. Czapiewski, G. Strauchold, Wrocław 2009, s. 165-177.

Zielecki A., Szkolna mapa historyczna jako narracja historyczno-dydaktyczna, w: Mapa w pracy historyka, red. T. Bogacz, B. Konopska, Wrocław-Warszawa 1999, s. 131-144 (Z Dziejów Kartografii, 11).

Zmowa. IV rozbiór Polski, oprac. A.L. Szcześniak, Warszawa 1990.

Wyższej Szkoły Zarządzania i Bankowości w Poznaniu", 11 (5), 2006, s. 171-184; Л.М. Аржакова, В.А. Якубский, К вопросу об освещении событий сентября 1939 в учебной и научно-популярной литературе, „Studia Slavica et Balcanica Petropolitana [St. Petersburg]", 1-2 (5-6), 2009, s. 37-44; Kampf der Karten. Propagandaund Geschichtskarten als politische Instrumente und Identitätstexte, hrsg. P. Haslinger, V. Oswalt, Marburg 2012. 


\section{0th century East-Central Europe in the Russian and Belorussian historical atlases edited at the beginning of the 21th century (2005-2010)}

\section{Summary}

Both in Russia and Belarus traditional paper atlases are still published. Considering large compilations with scholarly ambitions, the majority of cartographic works embrace Russian publications. For the last several decades, after the collapse of the Soviet Union, in the area of historical geography and modern history some historical revaluation took place in the successive countries of the USSR. Naturally, the process has not been completed yet. Its course has been influenced by maintain-

ing in Russia and Belarus at least authoritarian forms of government; though, with democratic elements. Historical atlases from the two countries that neighbor Poland in the East cover new contents, which could be published only after 1991. At the same time, numerous judgments and historical interpretations to be found there are not in compliance with the statements accepted in Poland and reflected in Polish publications on historical geography.

Słowa kluczowe: atlas, geopolityka, granice, terytorium, historia, komunizm

Keywords: atlas, geopolitics, borders, territory, history, communism

prof. dr hab. Grzegorz Strauchold - kierownik Zakładu Historii Najnowszej oraz Pracowni Atlasu Historycznego w Instytucie Historycznym Uniwersytetu Wrocławskiego (e-mail: strauchold@tlen.pl) 